\title{
ANALISIS MANUFACTURING CYCLE EFFECTIVENESS (MCE) DALAM MENGURANGI NON-VALUE-ADDED ACTIVITIES PADA PG KANIGORO MADIUN
}

\author{
Alwiyanti Kusuma Wardani \\ IKIP PGRI Madiun \\ al8894wy@gmail.com

\section{Drs. Supri Wahyudi Utomo, M.Pd IKIP PGRI Madiun}

\author{
Purweni W, S.E., M.M \\ IKIP PGRI Madiun
}

\begin{abstract}
ABSTRAK
Penelitian ini bertujuan untuk memberikan bukti empiris mengenai penerapan Manufacturing Cycle Effectiveness (MCE) sebagai alat ukur dalam mengurangi aktivitas tidak bernilai tambah (non-value-added activities) pada produksi gula kristal putih Pabrik Gula (PG) Kanigoro Madiun tahun 2013 dan 2014. Penelitian ini merupakan penelitian kualitatif dengan data primer berupa informasi-informasi aktivitas dan waktu produksi yang dikumpulkan melalui metode wawancara dan observasi. Sedangkan data sekunder berupa laporan kinerja produksi dan rencana kerja anggaran perusahaan (RKAP).

Hasil penelitian ini menunjukkan bahwa sebagian besar aktivitas pada produksi gula kristal putih di PG Kanigoro Madiun masih memuat aktivitas tidak bernilai tambah (nonvalue-added activities). Hal ini dibuktikan dengan hasil perhitungan Manufacturing Cycle Effectiveness (MCE) pada tahun 2013 dan 2014 masing-masing sebesar 96,59\% dan 97,19\%, sehingga persentase non-value-added activities pada tahun 2013 dan 2014 masing-masing sebesar $3,41 \%$ dan $2,81 \%$. Adanya aktivitas tidak bernilai tambah disebabkan tata letak pabrikasi yang dirasa kurang efektif. Jarak antar mesin produksi dengan stamp floor mengakibatkan munculnya aktivitas inspeksi, perpindahan dan waktu tunggu. Oleh karena itu, perusahaan perlu memilih alternatif perbaikan kinerja melalui pengurangan, eliminasi, maupun substitusi aktivitas sehingga cost effectiveness dapat tercapai.
\end{abstract}

Kata Kunci : Manufacturing Cycle Effectiveness (MCE), Aktivitas Tidak Bernilai Tambah (Non-Value-Added Activities), Efisiensi dan Efektifitas.

\section{PENDAHULUAN}

Era globalisasi menyebabkan tidak ada lagi batasan antar Negara, sehingga perusahaan menghadapi persaingan yang semakin tajam, sehingga setiap perusahaan dituntut untuk meningkatkan daya saingnya melalui produksi produk dan jasa secara cost efficiency dan cost effective. Untuk mewujudkan keduanya, maka manajemen harus melakukan pengelolaan terhadap berbagai aktivitas yang menyebabkan timbulnya pemborosan dan tidak efektifnya waktu selama proses produksi untuk menghasilkan value bagi customer. Efisiensi dan efektivitas aktivitas operasional dapat dicapai melalui manajemen aktivitas yang tidak bernilai tambah (non-value-added activities), sehingga pengurangan waktu akibat aktivitas tidak bernilai tambah tidak hanya mempercepat respon kepada pelanggan tetapi juga akan berdampak pada pengurangan biaya karena sumber daya yang dipakai semakin sedikit. Hal ini 
merupakan kunci keberhasilan pengendalian bagi perusahaan dalam lingkungan perbaikan berkelanjutan.

Menurut penelitian yang dilakukan Verdiyanti dan El-Maghviroh (2013) menyatakan bahwa perubahan cara pandang mengenai metode yang dipakai oleh manajemen untuk mengelola perusahaan menyebabkan perubahan informasi biaya yang mereka butuhkan, sehingga konsep cost efficiency digantikan dengan konsep cost effectiveness menggunakan alat analisis Manufacturing Cycle Effectiveness (MCE). Manufacturing Cycle Effectiveness (MCE) dihitung dengan membandingkan processing time dengan cycle time, kemudian menghasilkan ukuran yang menunjukkan presentase value-added activities yang terdapat dalam suatu aktivitas produksi yang digunakan oleh perusahaan untuk menghasilkan value bagi customer. Jika proses pembuatan produk menghasilkan Manufacturing Cycle Effectiveness (MCE) sebesar 1 atau 100\%, maka aktivitas bukan penambah nilai telah dapat dihilangkan dalam proses pengolahan produk, sehingga customer tidak dibebani dengan biaya-biaya untuk aktivitas bukan penambah nilai bagi mereka. Sebaliknya, jika Manufacturing Cycle Effectiveness (MCE) kurang dari 1 atau kurang dari 100\%, berarti proses pengolahan produk masih mengandung aktivitas bukan penambah nilai bagi customer.

Keberadaan industri gula di Indonesia memegang peranan penting bagi masyarakat dan sektor industri lainnya. Kota Madiun sebagai Kota "Gadis" (Perdagangan dan Industri) berkontribusi dalam industri gula nasional melalui Pabrik Gula (PG) Kanigoro yang merupakan salah satu unit usaha PT Perkebunan Nusantara (PTPN) XI Surabaya yang bergerak dalam bidang pengolahan tebu menjadi gula. Kedudukan gula sebagai bahan pemanis utama di Indonesia memang belum dapat tergantikan oleh bahan pemanis lainnya. Jenis gula yang sering dikonsumsi masyarakat pada umumnya adalah Gula Kristal Putih (GKP), yang merupakan gula Kristal terbuat dari tebu atau bit melalui proses sulfitasi/karbonasi/fosfatasi atau proses lainnya sehingga langsung dapat dikonsumsi. Berkaitan dengan proses pembuatan gula Kristal putih, maka terjadi indikasi terdapat kompleksitas aktivitas, sumber daya dan waktu yang dibutuhkan mulai dari proses penanganan bahan baku sampai menjadi gula kristal putih yang siap jual. Lamanya waktu yang digunakan untuk memproduksi bahan baku akan mempengaruhi kualitas yang diinginkan oleh customer. Selain itu juga mempengaruhi besaran biaya yang ditimbulkan. Hal tersebut membuat peneliti tertarik dan terdorong untuk melakukan penelitian mengenai seberapa efektif aktivitas yang terjadi pada kegiatan proses produksi tebu sehingga dapat mencapai cost effectiveness dan telah mampu mengurangi non-value-added activities pada Pabrik Gula Kanigoro Madiun dengan batasan masa giling tahun 2013 dan tahun 2014.

\section{KAJIAN PUSTAKA}

\section{Konsep Value-Added dan Non-Value-Added Activities}

Aktivitas-aktivitas yang harus dipertahankan dalam bisnis disebut dengan aktivitas penambah nilai (value-added activities). Menurut Riwayadi (2014: 31) "aktivitas nilai tambah (value-added activities) adalah aktivitas yang memberikan nilai (value) kepada pelanggan.” Kemudian Raiborn dan Kinney (2011: 151) mengemukakan bahwa aktivitas bernilai tambah (value-added activities) meningkatkan manfaat dari suatu produk atau jasa untuk pelanggan dan merupakan salah satu alasan pelanggan akan membayarnya. 
Sedangkan aktivitas-aktivitas yang bukan prioritas dan harus menjadi fokus utama manajemen disebut dengan aktivitas tidak bernilai tambah (non-value-added activities). Siregar et al (2013: 258) berpendapat bahwa aktivitas tidak bernilai tambah (non-value-added activities) adalah suatu aktivitas yang mengkonsumsi waktu, sumber daya, atau tempat tetapi hanya memberikan sedikit nilai tambah bagi kepuasan konsumen atau bahkan sama sekali tidak memberikan nilai tambah. Jika aktivitas ini dihilangkan, nilai atau kepuasan konsumen tidak akan berkurang. Selain itu, Hansen dan Mowen (2015: 232-233) menjelaskan bahwa biaya tidak bernilai tambah adalah berbagai biaya yang disebabkan oleh aktivitas-aktivitas tidak bernilai tambah atau kinerja yang tidak efisien dari aktivitas bernilai tambah, sehingga muncul berbagai usaha untuk mengurangi biaya tersebut.

Berdasarkan pemaparan di atas maka disimpulkan bahwa aktivitas bernilai tambah (value-added-activities) merupakan semua aktivitas yang dianggap penting, diprioritaskan dan harus dipertahankan oleh perusahaan untuk meningkatkan nilai produk atau jasa untuk konsumen. Sedangkan aktivitas tidak bernilai tambah (non-value-added activities) merupakan aktivitas yang dianggap bukan bukan prioritas yang menimbulkan pemborosan biaya dan waktu, apabila dihilangkan tidak mengurangi nilai kepada pelanggan karena pelanggan tidak mendapatkan manfaat secara langsung dari aktivitas tersebut.

\section{Teori-teori yang Berkaitan dengan Value-Added dan Non-Value-Added Activities}

a. Teori Efisiensi

Krismiaji dan Aryani (2011: 359) mengemukakan bahwa ukuran efisiensi digunakan untuk menentukan apakah suatu unit bisnis telah menggunakan sumberdaya dan proses internal dengan efisien. Fokus ukurannya antara lain kualitas, waktu, dan efisiensi. Kemudian, menurut Siregar et al (2013: 299-300), manajemen membutuhkan ukuran keuangan dan ukuran fisik untuk mengetahui seberapa baik mereka mengelola proses dan aktivitas dalam organisasi. Adapun ukuran-ukuran yang biasa digunakan untuk efisiensi produksi dan bisnis, diantaranya (a) produktivitas, (b) waktu siklus (cycling time), dan (c) rasio output.

b. Teori Produktivitas

Sedarmayanti (2009: 58) menyebutkan bahwa produktivitas memiliki dua dimensi produktivitas kinerja yakni efektivitas dan efisiensi. Dimensi pertama berkaitan dengan pencapaian untuk kinerja yang maksimal, dalam arti pencapaian target yang berkaitan dengan kualitas, kuantitas dan waktu. Sedangkan dimensi kedua berkaitan dengan upaya membandingkan masukan dengan realisasi penggunaannya atau bagaimana pekerjaan tersebut dilaksanakan.

Berdasarkan pemaparan kedua teori diatas, maka disimpulkan bahwa unsur waktu merupakan fokus utama dan kunci keberhasilan manajemen aktivitas dalam proses produksi sehingga menghasilkan value bagi customer.

\section{Konsep Manufacturing Cycle Effectiveness (MCE)}

Menurut Mulyadi (2007: 713) Manufacturing Cycle Effectiveness (MCE) atau Cycle Effectiveness (CE) merupakan ukuran yang menunjukkan persentase value-added activities yang terdapat dalam aktivitas yang digunakan perusahaan untuk menghasilkan value bagi customer. Kemudian, Saftiana et al (2007: 112) mengemukakan bahwa Manufacturing Cycle 
Effectiveness (MCE) merupakan alat analisis terhadap aktivitas-aktivitas produksi, misalanya berapa lama waktu yang dikonsumsi oleh suatu aktivitas mulai penanganan bahan baku, produk dalam proses hingga produk jadi (cycling time). Manufacturing Cycle Effectiveness (MCE) dihitung dengan memanfaatkan data cycle time atau throughput time yang telah dikumpulkan.

Pemilahan cycle time dapat dilakukan dengan melakukan activity analysis. Hansen dan Mowen (2015: 230) berpendapat bahwa analisis aktivitas (activity analysis) adalah untuk mengidentifikasi, menjelaskan, dan mengevaluasi berbagai aktivitas yang dilakukan perusahaan, yang dilakukan melalui empat cara: (1) eliminasi aktivitas; (2) pemilihan aktivitas; (3) pengurangan aktivitas; dan (4) penyatuan aktivitas. Analisis aktivitas membagi berbagai aktivitas ke dalam empat golongan waktu tidak bernilai tambah, seperti tergambar dalam skema di bawah ini.

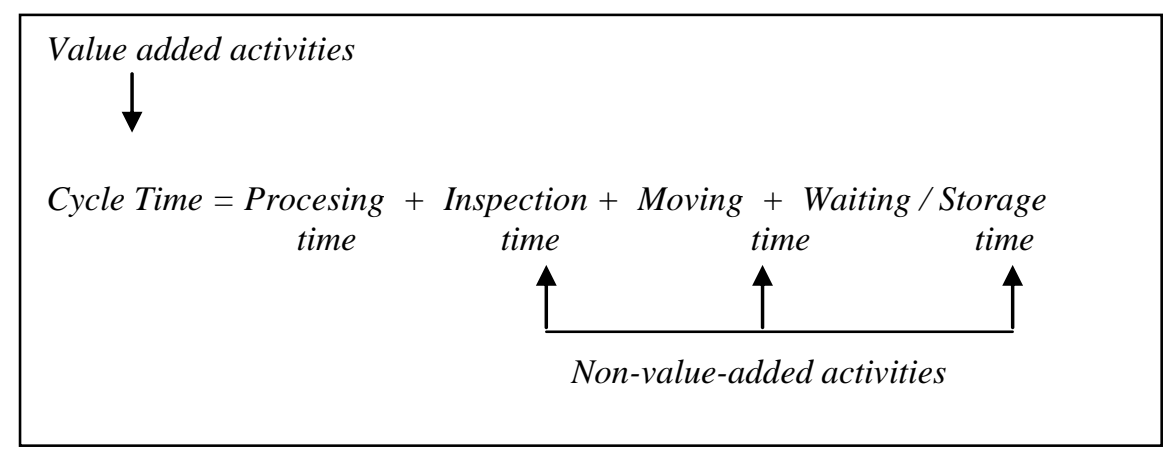

Gambar 1. Skema aktivitas perusahaan

Setelah dilakukan activity analysis, akan dilakukan perhitungan Manufacturing Cycle Effectiveness (MCE). Agustina et al (2007: 144) memformulasikan Manufacturing Cycle Effectiveness (MCE) sebagai berikut:

$$
\text { Manufacturing Cycle Effectiveness (MCE) }=\frac{\text { Processing Time }}{\text { Processing Time }+ \text { Inspection Time }+ \text { Waiting Time }+ \text { Move Time }}
$$

Proses produksi yang ideal akan menghasilkan throughput atau cycle time yang sama dengan processing time. Jika proses pembuatan produk menghasilkan Manufacturing Cycle Effectiveness (MCE) sebesar 1 atau 100\%, maka aktivitas bukan penambah nilai telah dapat dihilangkan dalam proses pengolahan produk, sehingga customer tidak dibebani dengan biaya-biaya untuk aktivitas bukan penambah nilai bagi mereka. Sebaliknya, jika Manufacturing Cycle Effectiveness (MCE) kurang dari 1 atau kurang dari 100\%, berarti proses pengolahan produk masih mengandung aktivitas bukan penambah nilai bagi customer. Ukuran Manufacturing Cycle Effectiveness (MCE) dapat digunakan oleh manajemen untuk merencanakan program improvement melalui pengurangan dan penghilangan non-valueadded activities. 


\section{METODE PENELITIAN}

\section{Tempat dan Waktu Penelitian}

Penelitian ini dilakukan di Pabrik Gula Kanigoro Madiun, yang bertempat di Jalan Kapten Tendean No. 24, Kecamatan Wungu, Kabupaten/Kota Madiun. PG Kanigoro merupakan unit usaha PTPN XI Surabaya yang bergerak dalam industri pengolahan tebu menjadi gula Kristal. Berkaitan dengan proses produksinya, maka terdapat indikasi kompleksitas aktivitas, sumber daya dan waktu yang dibutuhkan mulai dari proses penanganan bahan baku sampai menjadi gula kristal putih yang siap jual. Sehingga, efektifitas dan efisiensi proses menjadi fokus utama penelitian. Penelitian ini dilakukan selama 6 bulan, yaitu mulai bulan Februari sampai dengan bulan Juli 2016.

\section{Prosedur Penelitian}

Fokus penelitian ini adalah pada persentase non-value added activities yang dihitung dengan formula Manufacturing Cycle Effectiveness (MCE), kemudian dianalisis secara deskriptif-kualitatif sehingga didapatkan hasil penelitian sebagai bukti empiris kinerja efektivitas waktu produksi yang sustainable atau evaluasi untuk melakukan continous improvement. Berikut ini disajikan kerangka penelitian yang akan dilaksanakan.

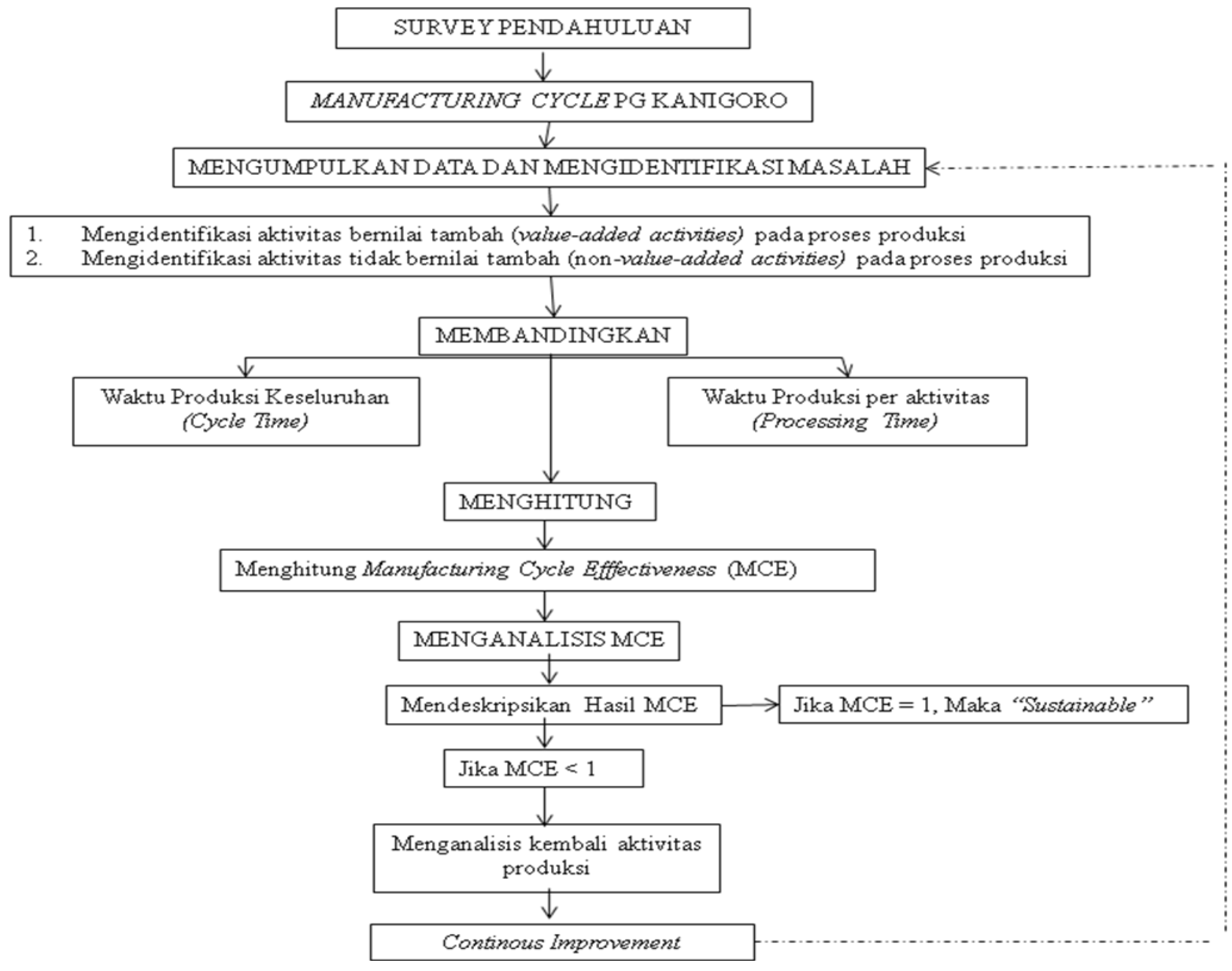

Gambar 2. Kerangka Penelitian 


\section{Teknik Pengumpulan Data}

Teknik pengumpulan data dalam penelitian ini adalah menggunakan wawancara dan dokumentasi. Wawancara dilakukan dengan narasumber asisten manajer departemen produksi mengenai data lamanya waktu inspeksi, waktu tunggu, waktu pemindahan, waktu proses, jadwal produksi, aktivitas-aktivitas yang dilakukan dalam proses produksi, data kuantitatif bahan baku yang diolah, daftar departemen yang terlibat dalam proses produksi, langkahlangkah produksi, serta faktor-faktor yang mempengaruhi proses produksi. Selain itu, wawancara dilakukan dengan kepala divisi sumber daya manusia PG Kanigoro Madiun dan PTPN XI Surabaya terkait company profile dan stakeholder. Sedangkan teknik dokumentasi menggunakan catatan, arsip, gambar-gambar, flow-chart diagram, maupun skema alur proses kerja yang dikumpulkan dengan alat bantu kamera, scanner, maupun download file.

\section{Teknik Keabsahan Data}

Penelitian ini memilih tiga teknik keabsahan data kualitatif, antara lain uji kredibilitas dengan cara kombinasi triangulasi sumber dan triangulasi teknik pengumpulan data, uji dependability melalui audit terhadap keseluruhan aktivitas peneliti dalam proses penelitian oleh dosen pembimbing, serta uji konfirmability dilakukan dengan cara membandingkan dan mengkomunikasikan setiap langkah dan hasil penelitian dengan dosen pembimbing maupun pihak PG Kanigoro Madiun.

\section{Teknik analisis data}

Pada penelitian ini analisis data dilakukan secara deskriptif-kualitatif, yaitu membandingkan data processing time dan cycling time serta menggunakan alat analisis berupa formula Manufacturing Cycle Effectiveness (MCE). Pada tahap akhir analisis data, ukuran persentase dan hasil deskripsi hasil analisis Manufacturing Cycle Effectiveness (MCE) dapat digunakan oleh manajemen sebagai bukti empiris tingkat kinerja efisiensi dan efektifitas waktu produksi.

\section{PAPARAN DATA DAN TEMUAN LAPANGAN}

Proses pembuatan gula Kristal putih melibatkan enam stasiun besar dan berbagai aktivitas kompleks yang menggunakan sumber daya beraneka ragam di dalamnya. Berikut ini disajikan skema proses pembuatan gula Kristal putih pada PG Kanigoro Madiun. 


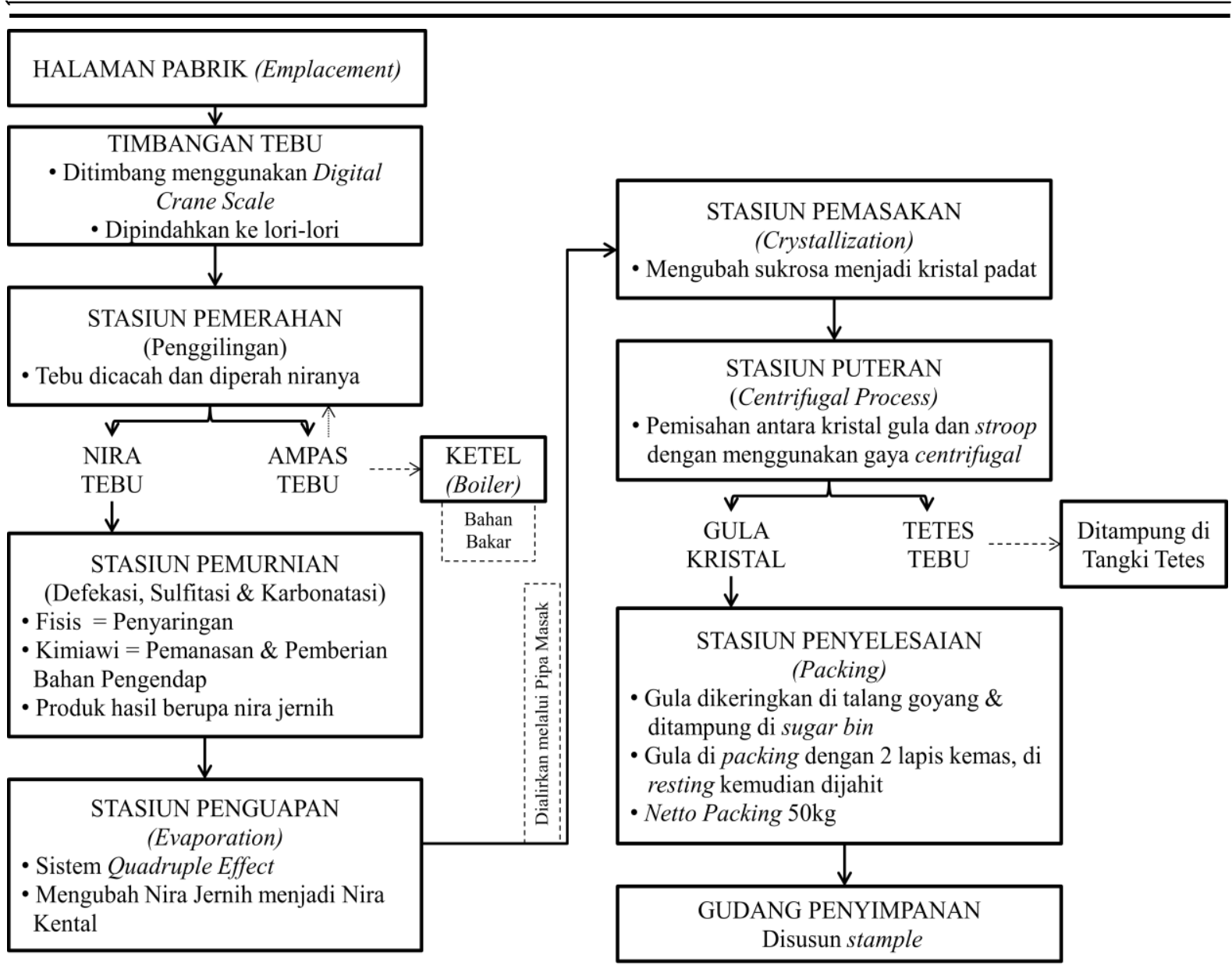

Gambar 3. Proses Pembuatan Gula Kristal Putih

Selain data berupa aktivitas-aktivitas dari enam stasiun besar diatas, peneliti juga memaparkan temuan lapangan bahwa pada tahun 2013 dan 2014, PG Kanigoro Madiun memiliki kapasitas giling normal sebesar 1.900 TCD dan beroperasi selama 24 jam non-stop dalam 7 hari seminggu. Operasional tersebut terbagi menjadi 3 shift dalam satu hari dimana dalam satu shift membutuhkan waktu 8 jam, sehingga dalam satu hari terdapat 3 shift. Untuk memproduksi gula Kristal putih, PG Kanigoro membutuhkan waktu selama \pm 48 jam dalam satu siklus produksi, artinya bahwa setiap satu kali siklus produksi sama dengan 6 shift kerja sama dengan 2 hari waktu operasi pabrik. Pada tahun 2013, PG Kanigoro menghabiskan 119 hari giling untuk memproses seluruh tebu menjadi gula Kristal putih. Hal ini berarti bahwa PG menghabiskan waktu selama 119 hari x 24 jam yaitu 2.856 jam atau sebanyak 59,5 kali siklus produksi dengan prosentase jam berhenti sebesar 22,34\%. Sedangkan tahun 2014, PG Kanigoro menghabiskan 83 hari giling, atau selama 83 hari x 24 jam yaitu 1.992 jam atau sebanyak 41,5 kali siklus produksi dengan prosentase jam berhenti sebesar 15,45\%. Di bawah ini disajikan tabel rekapitulasi konsumsi waktu dari enam stasiun besar pengolahan gula pada PG Kanigoro Madiun. 
Tabel 1. Rekapitulasi Konsumsi Waktu Pengolahan Gula

\begin{tabular}{|c|c|c|c|}
\hline \multirow{2}{*}{ No } & \multirow{2}{*}{$\begin{array}{l}\text { Aktivitas Manufaktur dalam } \\
\text { Produksi Gula Kristal Putih }\end{array}$} & \multicolumn{2}{|c|}{$\begin{array}{c}\text { Jumlah Konsumsi Waktu per } \\
\text { Siklus }\end{array}$} \\
\hline & & $\begin{array}{l}\text { Th. } 2013 \\
\text { (Menit) }\end{array}$ & $\begin{array}{l}\text { Th. } 2014 \\
\text { (Menit) }\end{array}$ \\
\hline 1 & Emplasemen Pabrik & 41,86 & 38,5 \\
\hline 2 & Stasiun Gilingan & 158,8 & 144,83 \\
\hline 3 & Stasiun Pemurnian dan Pengolahan & 662,62 & 662,87 \\
\hline 4 & Stasiun Pengolahan & 1780,95 & 1779,95 \\
\hline 5 & Stasiun Puteran dan Penyelesaian & 235,77 & 214,6 \\
\hline \multicolumn{2}{|r|}{ TOTAL WAKTU TERKONSUMSI PER SIKLUS } & 2880 & 2840,75 \\
\hline \multicolumn{2}{|r|}{ TOTAL WAKTU TERKONSUMSI DALAM MASA GILING } & 171.360 & $117.891,125$ \\
\hline
\end{tabular}

\section{PEMBAHASAN}

\section{A. Perhitungan Value-Added dan Non-Value Added Activities}

Dalam proses produksi gula Kristal putih pada PG Kanigoro Madiun, sebagian besar aktivitasnya sudah mengalami modernisasi, yaitu dengan menggantikan fungsi tenaga manusia ke tenaga mesin sehingga lebih cepat, praktis, dan efisien. Namun, untuk beberapa aktivitas masih menggunakan tenaga manusia atau memang belum ada saranaprasarana baru. Berikut ini disajikan tabel waktu yang dipergunakan oleh aktivitasaktivitas yang terjadi dalam satu siklus produksi gula Kristal putih.

Tabel .2. Perhitungan Waktu Inspeksi PG Kanigoro

\begin{tabular}{|l|l|c|c|}
\hline \multirow{2}{*}{ No } & \multicolumn{1}{|c|}{ Aktivitas Manufaktur } & \multicolumn{2}{c|}{ Jumlah Konsumsi Waktu per } \\
\cline { 2 - 3 } & \multicolumn{1}{|c|}{ Siklus } \\
\cline { 2 - 4 } & \multicolumn{1}{|c|}{$\begin{array}{c}\text { Th. 2013 } \\
\text { (Menit) }\end{array}$} & $\begin{array}{c}\text { Th. 2014 } \\
\text { (Menit) }\end{array}$ \\
\hline 1 & Input data tebu giling dan klasifikasi mutu & 2 & 2 \\
\hline 3 & $\begin{array}{l}\text { Pengamatan Brix dan Pool tebu untuk mengetahui Hablur } \\
\text { Keluaran (HK) dan Rendemen per lori }\end{array}$ & 1,25 & 4,25 \\
\hline TOTALes input analisa Brix dan Pool tebu serta penyajian hasil \\
\hline TOTAL WAKTU TERKONSUMSI PER SIKLUS & 4,5 & 7,75 \\
\hline
\end{tabular}

Sumber : PG. Kanigoro Madiun, 2016

Tabel 3. Perhitungan Waktu Perpindahan PG Kanigoro

\begin{tabular}{|l|l|c|c|}
\hline \multirow{2}{*}{ No } & \multicolumn{1}{|c|}{ Aktivitas Manufaktur } & \multicolumn{2}{c|}{ Jumlah Konsumsi Waktu per } \\
Siklus \\
\cline { 2 - 4 } & \multicolumn{1}{|c|}{$\begin{array}{c}\text { Th. 2013 } \\
\text { (Menit) }\end{array}$} & $\begin{array}{c}\text { Th. 2014 } \\
\text { (Menit) }\end{array}$ \\
\hline 1 & $\begin{array}{l}\text { Pemindahan gula produk yang telah ditimbang dari pos } \\
\text { penimbangan ke stamp floor dalam keadaan belum dijahit }\end{array}$ & 35,25 & 30,15 \\
\hline 2 & $\begin{array}{l}\text { Pemindahan gula produk yang telah selesai dijahit menuju } \\
\text { gudang penyimpanan }\end{array}$ & 27 & 25 \\
\hline \multicolumn{2}{|c|}{ TOTAL WAKTU TERKONSUMSI PER SIKLUS } & 62,25 & 55,15 \\
\hline \multicolumn{2}{|c|}{ TOTAL WAKTU TERKONSUMSI DALAM MASA GILING } & $3.703,875$ & $2.288,725$ \\
\hline
\end{tabular}

Sumber : PG. Kanigoro Madiun, 2016 
Tabel 5.4. Perhitungan Waktu Tunggu PG Kanigoro

\begin{tabular}{|c|c|c|c|}
\hline \multirow{2}{*}{ No } & \multirow{2}{*}{ Aktivitas Manufaktur } & \multicolumn{2}{|c|}{$\begin{array}{c}\text { Jumlah Konsumsi Waktu per } \\
\text { Siklus }\end{array}$} \\
\hline & & $\begin{array}{l}\text { Th. } 2013 \\
\text { (Menit) }\end{array}$ & $\begin{array}{l}\text { Th. } 2014 \\
\text { (Menit) }\end{array}$ \\
\hline 1 & Penyimpanan di stamp floor & 7 & 5 \\
\hline \multicolumn{2}{|r|}{ TOTAL WAKTU TERKONSUMSI PER SIKLUS } & 7 & 5 \\
\hline TOT & AL WAKTU TERKONSUMSI DALAM MASA GILING & 416,5 & 207,5 \\
\hline
\end{tabular}

Sumber : PG Kanigoro Madiun, 2016

Tabel 5.5. Perhitungan Waktu Proses Produksi pada PG Kanigoro

\begin{tabular}{|c|c|c|c|}
\hline \multirow{2}{*}{ No } & \multirow{2}{*}{ Aktivitas Manufaktur } & \multicolumn{2}{|c|}{$\begin{array}{l}\text { Jumlah Konsumsi Waktu per } \\
\text { Siklus }\end{array}$} \\
\hline & & $\begin{array}{l}\text { Th. } 2013 \\
\text { (Menit) }\end{array}$ & $\begin{array}{l}\text { Th. } 2014 \\
\text { (Menit) }\end{array}$ \\
\hline 1 & Proses penimbangan tebu sekaligus pemindahan ke lori & 33,5 & 30,5 \\
\hline 2 & Pemindahan tebu dari lori ke meja tebu sebelum digiling & 8,36 & 8 \\
\hline 3 & Proses tebu di stasiun gilingan & 98,55 & 84,58 \\
\hline 4 & Input data tebu giling dan klasifikasi mutu & 2 & 2 \\
\hline 5 & $\begin{array}{l}\text { Pengamatan dan penentuan kapasitas tebu giling per } \\
\text { menggunakan komputer otomatis }\end{array}$ & 1 & 1 \\
\hline 6 & $\begin{array}{l}\text { Pengambilan sampel Nira dan Pool Perahan (NPP) untuk analisa } \\
\text { kimia }\end{array}$ & 0,75 & 0,75 \\
\hline 7 & $\begin{array}{l}\text { Pengamatan Brix dan Pool tebu untuk mengetahui Hablur } \\
\text { Keluaran (HK) dan Rendemen per lori }\end{array}$ & 1,25 & 1,25 \\
\hline 8 & $\begin{array}{l}\text { Proses input analisa Brix dan Pool tebu serta penyajian hasil } \\
\text { rendemen pada komputer }\end{array}$ & 4,5 & 4,5 \\
\hline 9 & $\begin{array}{l}\text { Proses penimbangan nira mentah beserta pemanasan nira mentah } \\
\text { pada Pan Pemanas I }\end{array}$ & 50,75 & 50,75 \\
\hline 10 & Proses pemurnian nira dalam stasiun pemurnian & 177,56 & 177,56 \\
\hline 11 & Pengamatan kadar $\mathrm{pH}$ nira dalam proses pemurnian & 6,25 & 6,5 \\
\hline 12 & $\begin{array}{l}\text { Proses pemisahan nira dan kotoran sehingga menghasilkan Nira } \\
\text { Encer (NE), Nira Tapis (NT), serta Blotong }\end{array}$ & 58,06 & 58,06 \\
\hline 13 & $\begin{array}{l}\text { Proses pemanasan dan evaporasi Nira Encer (NE) pada stasiun } \\
\text { penguapan }\end{array}$ & 420,75 & 420,75 \\
\hline 14 & Proses kristalisasi & 1746,57 & 1746,57 \\
\hline 15 & Proses komputerisasi data laboratorium pengolahan & 4 & 3 \\
\hline 16 & $\begin{array}{l}\text { Proses pendinginan dan kristalisasi lanjutan pada palung } \\
\text { pendingin }\end{array}$ & 30,38 & 30,38 \\
\hline 17 & Tahap sentrifugasi atau pemisahan gula kristal dengan molase & 18,53 & 18,53 \\
\hline 18 & Pemasangan karung gula pada sugar bin secara manual & 40 & 35 \\
\hline 19 & $\begin{array}{l}\text { Pemindahan karung gula dari bawah sugar bin ke timbangan } \\
\text { tokok }\end{array}$ & 50 & 48,25 \\
\hline 20 & Proses menimbang gula yang telah di packing & 30 & 25 \\
\hline 22 & Waktu resting gula di stamp floor sebelum dijahit & 14,67 & 14,67 \\
\hline 23 & Proses menjahit karung gula di stamp floor & 13,32 & 13 \\
\hline \multicolumn{2}{|c|}{ TOTAL WAKTU TERKONSUMSI } & 2810,75 & 2780,6 \\
\hline \multicolumn{2}{|c|}{ WAKTU BERHENTI } & 627,92155 & 429,6027 \\
\hline \multicolumn{2}{|r|}{ TOTAL WAKTU PROSES SESUNGGUHNYA } & 2182,82845 & 2350,9973 \\
\hline
\end{tabular}

Sumber : PG. Kanigoro Madiun, 2016

\section{B. Perhitungan Manufacturing Cycle Effectiveness (MCE)}

Manufacturing Cycle Effectiveness (MCE) dihitung dengan membandingkan waktu proses (processing time) dengan keseluruhan waktu produksi (cycle time). Berikut ini 
dipaparkan perhitungan Manufacturing Cycle Effectiveness (MCE) pada PG Kanigoro Madiun.

$\mathrm{R}_{1}:$ Cycle time $=$ processing time + waiting time + moving time + inspection time

\begin{tabular}{|l|c|c|c|c|}
\hline \multirow{2}{*}{$\begin{array}{c}\text { Komponen Cycling } \\
\text { Time }\end{array}$} & \multicolumn{2}{|c|}{ Tahun 2013 } & \multicolumn{2}{c|}{ Tahun 2014 } \\
\cline { 2 - 5 } & $\begin{array}{c}\text { Per siklus } \\
\text { (Menit) }\end{array}$ & $\begin{array}{c}\text { Total } \\
\text { (Menit) }\end{array}$ & $\begin{array}{c}\text { Per siklus } \\
\text { (Menit) }\end{array}$ & $\begin{array}{c}\text { Total } \\
\text { (Menit) }\end{array}$ \\
\hline Processing & $2.182,82845$ & $129.878,2928$ & $2.350,9973$ & $97.566,38795$ \\
\hline Waiting & 7 & 416,5 & 5 & 207,5 \\
\hline Moving & 62,25 & $3.703,875$ & 55,15 & $2.288,725$ \\
\hline Inspection & 7,75 & 461,125 & 7,75 & 321,625 \\
\hline Total Cycle Time & $2.259,82845$ & $134.459,7928$ & $2.418,8973$ & $100.384,238$ \\
\hline
\end{tabular}

Sumber : PG Kanigoro Madiun, 2016

$$
\mathrm{R}_{2}: \text { Manufacturing Cycle Effectiveness }(\mathrm{MCE})=\underline{\text { Processsing Time }} \times 100 \%
$$

Cycle Time

\begin{tabular}{|c|c|c|c|c|}
\hline Keterangan & Satuan & 2013 & 2014 & Selisih \\
\hline \multicolumn{5}{|l|}{ Value Added Activities } \\
\hline Processing Time & Menit & $129.878,2928$ & $97.566,38795$ & $32.311,90485$ \\
\hline \multicolumn{5}{|l|}{ Non-Value Added Activities } \\
\hline Inspection Time & Menit & 461,125 & 321,625 & 139,5 \\
\hline Moving Time & Menit & $3.703,875$ & $2.288,725$ & $1.415,15$ \\
\hline Waiting Time & Menit & 416,5 & 207,5 & 209 \\
\hline Total Cycle Time & Menit & $134.459,7928$ & $100.384,238$ & $34.075,5548$ \\
\hline $\begin{array}{l}\text { Manufacturing Cycle Effectiveness } \\
\text { (MCE) }\end{array}$ & $\%$ & 96,59 & 97,19 & $-0,6$ \\
\hline \% Aktivitas Tidak Bernilai Tambah & $\%$ & 3,41 & 2,81 & 0,6 \\
\hline Total Biaya Produksi & $\mathrm{Rp}$ & 4.134.909.586,- & 3.594.361.641,- & 540.547.945,- \\
\hline $\begin{array}{l}\text { Total Biaya Tidak Bernilai Tambah } \\
\text { dari Total Biaya Produksi }\end{array}$ & $\mathrm{Rp}$ & 141.000.417,- & 101.001.562,- & 39.998.855,-- \\
\hline
\end{tabular}

Sumber : PG Kanigoro Madiun, 2016

\section{Analisis Hasil Perhitungan Manufacturing Cycle Effectiveness (MCE) dan Konversi Biaya Tidak Bernilai Tambah}

Tahun 2013 hasil perhitungan Manufacturing Cycle Effectiveness (MCE) adalah sebesar 96,59\% atau masih terdapat 3,41\% (100\% - 96,59\%) aktivitas tidak bernilai tambah (non-value added activities). Sedangkan tahun 2014 hasil perhitungan Manufacturing Cycle Effectiveness (MCE) adalah sebesar 97,19\% atau masih terdapat 2,81\% (100\% - 97,19\%) aktivitas tidak bernilai tambah (non-value added activities). Peningkatan selisih positif efisiensi waktu manufaktur terjadi sebesar 0,6\% dari tahun 2013 ke tahun 2014. Hal ini ditunjukkan dengan selisih waktu angka negatif yang berarti peningkatan bagi efisiensi waktu.

Berdasarkan hasil observasi serta pemaparan dari Kepala Seksi Lingkungan PG Kanigoro, peningkatan efisiensi terjadi disebabkan masa giling pada tahun 2014 lebih pendek daripada tahun 2013, selain itu adanya pembaruan beberapa komponen mesin produksi pada stasiun puteran, kemudian adanya perubahan lay out pabrik mengenai pengaturan tebu masuk ke stasiun giling serta letak stamp floor yang lebih dekat dengan stasiun penyelesaian mengakibatkan waktu pemindahan dapat sedikit dipangkas. 
Peneliti memberikan tambahan berupa konversi biaya tidak bernilai tambah berdasarkan hasil perhitungan MCE diatas. Tahun 2013 PG Kanigoro menghabiskan total biaya produksi sebesar Rp. 4.134.909.586. Sedangkan tahun 2014 PG Kanigoro menghabiskan total biaya produksi sebesar Rp. 3.594.361.641,--. Berdasarkan perkiraan total biaya tersebut, maka dapat diasumsikan bahwa dari total biaya tersebut sesungguhnya terdapat biaya tidak bernilai tambah sebesar persentase aktivitas tidak bernilai tambah. Untuk tahun 2013, dari Rp. 4.134.909.586,- total biaya produksinya terdapat Rp. 141.000.417,- biaya tidak bernilai tambah. Sedangkan pada tahun 2014, dari total biaya produksi sebesar Rp. 3.594.361.641,- terdapat Rp. 101.001.562,- biaya tidak bernilai tambah. Jadi, sepanjang giling tahun 2013 dan 2014, PG Kanigoro Madiun melakukan pemborosan biaya sebesar Rp. 480.760.670,- untuk aktivitas-aktivitas tidak bernilai tambah.

Biaya tidak bernilai tambah tersebut berasal dari aktivitas-aktivitas tidak bernilai tambah yang termasuk ke dalam golongan waktu inspeksi, waktu perpindahan, dan waktu tunggu dalam siklus produksi. Aktivitas-aktivitas yang termasuk ke dalam tiga golongan waktu tersebut sebagian besar dilakukan oleh Sumber Daya Manusia (SDM).

\section{KESIMPULAN}

Pada tahun 2013 dan 2014, PG Kanigoro masih menggunakan tenaga sumber daya manusia dalam proses produksi untuk beberapa aktivitas manual seperti inspeksi, memindahkan gula produk, serta menjahit karung gula. Hal ini menjadikan tingkat efektivitas waktu produksi dan efisiensi biaya produksi terkonsentrasi pada aktivitas mesin dan tenaga manusia. Perbandingan perhitungan efektivitas waktu manufaktur (Manufacturing Cycle Effectiveness - MCE) pada PG Kanigoro tahun 2013 dan tahun 2014 dapat dikatakan belum efektif atau belum sustainable. Hal ini dibuktikan dengan hasil perhitungan yang menunjukkan persentase efektivitas kurang dari seratus persen. Sehingga, manajemen masih perlu meningkatkan fokus dalam perbaikan berkelanjutan (continous improvement) guna mengurangi aktivitas-aktivitas yang tidak mengandung nilai bagi customer.

\section{SARAN}

Adapun saran-saran yang dapat diberikan oleh peneliti antara lain:

1. Bagi manajemen PG Kanigoro Madiun agar lebih fokus terhadap manajemen aktivitas pada saat produksi gula kristal putih antara lain melalui alternatif langkah perbaikan dasar pembebanan biaya yang lebih jelas pada departemen produksi supaya aktivitas-aktivitas pemicu biaya dapat lebih mudah ditelusuri. Selain itu, manajemen dapat menerapkan alternatif penggantian sumber daya manusia menjadi tenaga mesin atau komputer (otomasi) serta melakukan evaluasi ulang tata letak antar sarana dan prasarana produksi supaya jarak yang ada lebih pendek dan mempercepat waktu yang digunakan dalam proses produksi. Melalui pengelolaan berbagai aktivitas, maka biaya yang ditimbulkan dari aktivitas-aktivitas tersebut dapat diminimalisasi sehingga diharapkan mampu mengurangi pemborosan yang terjadi.

2. Bagi penelitian selanjutnya supaya menambah fokus penelitian agar bisa lebih jelas diperoleh gambaran mengenai keterkaitan manajemen waktu aktivitas dengan upaya cost reduction. 


\section{DAFTAR PUSTAKA}

Agustina, Y., Sukmasari, D., dan Ermadiani. 2007. Analisa Penerapan Sistem Just In Time untuk Meningkatkan Efiisiensi dan Produktivitas pada Perusahaan Industri. Jurnal Akuntansi dan Keuangan. Vol. 12 No. 1. Januari 2007. Halm. 135-146.

Andriati, M.P. 2013. Analisis Manufacturing Cycle Efficiency (MCE) dalam Mengurangi Non-Value-Added Activities dan Dampaknya terhadap Value-Added Activities (Studi Kasus pada PT. Hini Daiki Indonesia). Jurnal Ekonomi, Bisnis dan Manajemen. Vol. 09 No. 14. Juni 2013. Halm. 91-116.

Anthony, R.N. dan Govindarajan, V. 2008. Management Control System: Sistem Pengendalian Manajemen. Edisi 11 Buku 1. Jakarta: Salemba Empat.

Ardiansyah, B. 2010. Analisis Manufacturing Cycle Effectiveness (MCE) dalam Mengurangi Non Value Added Activities (Studi Empiris pada Pabrik Minyak Kelapa Sawit PT. PPLI Asahan). Skripsi (Online). Semarang: Program Sarjana Fakultas Ekonomi Universitas Diponegoro, (http://eprints.undip.ac.id/22697/1/Skripsi.pdf, Diunduh 15 Februari 2016).

Arikunto, S. 2010. Prosedur Penelitian Suatu Pendekatan Praktik. Edisi Revisi. Jakarta: Rineka Cipta.

Ernawati, L., dan Suryani, E. 2013. Analisis Faktor Produktivitas Gula Nasional dan Pengaruhnya terhadap Harga Gula Domestik dan Permintaan Gula Impor dengan Menggunakan Sistem Dinamik. Jurnal Teknik POMITS. Vol 1 No. 1. Halm. 1-7.

Garrison, R.H., Noreen, E.W., dan Brewer, P.C. 2014. Akuntansi Manajerial. Edisi 14 Buku 1. Jakarta: Salemba Empat.

Hansen, D.R. dan Mowen., M.M. 2015. Akuntansi Manajerial. Edisi 8 Buku 1. Jakarta: Salemba Empat.

Katalog Badan Pusat Statistik Daerah No. 1101002.3577. 2014. Madiun: Badan Pusat Statistik Kota Madiun.

Krismiaji dan Aryani, Y.A. 2011. Akuntansi Manajemen. Edisi Kedua. Yogyakarta: UPP STIM YKPN.

Mardiasmo. 2009. Akuntansi Sektor Publik. Edisi IV. Yogyakarta: ANDI.

Marimin, Ismayana, A., dan Lohjayanti, A. 2016. Keragaan Kinerja dan Sistem Penunjang Keputusan Pengendalian Proses Produksi Gula Kristal di PT. Rajawali II Unit Pabrik Gula Jati Tujuh-Majalengka. Jurnal Teknik Industri Pertanian. Vol. 19 No. 3. (Online), (http://repository.ipb.ac.id/bitstream/handle/123456789/45673/1780-3084-1PB.pdf?sequence=1\&isAllowed=y, Diunduh 02 Maret 2016). Halm. 170-181.

Mariska, Dina. 2008. Aplikasi Activity Based Management untuk Meningkatkan Efisiensi Aktivitas Produksi di PT. X Sidoarjo. Undergraduate Theses. (Online), 
(http://digilib.its.ac.id/ITS-Undergraduate-3100007029919/2055, Diunduh 02 Maret 2016).

Moleong, L.J. 2015. Metodologi Penelitian Kualitatif. Edisi Revisi. Bandung: PT Remaja Rosdakarya.

Mulyadi. 2007. Sistem Perencanaan dan Pengendalian Manajemen: Sistem Pelipatgandaan Kinerja Perusahaan. Edisi 3. Jakarta: Salemba Empat.

Prihantoro, C.R. 2012. Konsep Pengendalian Mutu. Bandung: PT Remaja Rosdakarya.

PT Perkebunan Nusantara (PTPN) XI Surabaya. 2014. Unit Usaha PTPN XI Surabaya. (Online), (http://ptpn11.co.id/page/pabrik-gula, Diunduh 23 Maret 2016).

Raiborn, C.A. dan Kinney, M.R. 2011. Akuntansi Biaya: Dasar dan Perkembangan. Edisi 7 Buku 1. Jakarta: Salemba Empat.

2011. Akuntansi Biaya: Dasar dan Perkembangan. Edisi 7 Buku 2. Jakarta: Salemba Empat.

Riwayadi. 2014. Akuntansi Biaya. Jakarta: Salemba Empat.

Saftiana, Y., Ermadiani, dan Andriyanto, R.W. 2007. Analisis Manufactuirng Cycle Effectiveness dalam Meningkatkan Cost Effective pada Pabrik Pengolahan Kelapa Sawit. Jurnal Akuntansi dan Keuangan. Vol. 12 No. 1. Januari 2007. Halm. 107-121.

Sedarmayanti. 2009. Sumber Daya Manusia dan Produktivitas Kerja. Bandung: Mandar Maju.

Sherlita, E. 2010. Strategic Cost Reduction. FOKUS - Jurnal Akuntansi dan Manajemen. Vol. 2 No. 2. November 2010. Halm. 30-37.

Siregar, B., Suripto, B., Hapsoro, D., Widodo Lo, E. dan Biyanto, F. 2013. Akuntansi Manajemen. Jakarta: Salemba Empat.

Sugiyono. 2014. Metode Penelitian Kuantitatif, Kualitatif, dan R\&D. Bandung: CV Alfabeta.

Standar Nasional Indonesia No. 3140.3 Th. 2010 tentang Gula Kristal Putih. 2010. Jakarta: Badan Standarisasi Nasional.

Verdiyanti, R.T., dan El-Maghviroh, R. 2013. The Analysis of Manufacturing Cycle Effectiveness (MCE) in Reducing Non Value-Added Activities (Empirical Study at PT. Bhirawa Steel Surabaya). The Indonesian Accounting Review. Vol. 3 No. 2. Juli 2013. Halm. 149-160.

Warda, N.N., Herlina, L., dan Ferdinant, P.F. 2015. Peningkatan Kualitas Gula Rafinasi dengan Konsep Lean Manufacturing di PT Duta Sugar Internasional. Journal Industrial Services. Vol. 1 No. 1. Oktober 2015. Halm. 158-163. 
Wijayanto, I. 2016. Pengelolaan Value-Added Activities dan Non-Value-Added Activities melalui Analisis Manufacturing Cycle Effectiveness (MCE) dalam Meningkatkan Efisiensi Produksi (Studi Kasus pada UD Karya Tunggal Sidoarjo). AKUNESA Jurnal Akuntansi UNESA. Vol. 44 No. 2. (Online),(http://ejournal.unesa.ac.id/index.php/jurnal-akuntansi/article/ view/14712/baca-artikel, Diunduh 02 Maret 2016). Halm. 1-12.

Yin, R.K. 2015. Studi Kasus: Desain dan Metode. Edisi 1. Jakarta: Rajawali Pers. 